\title{
Erratum to: Youth Against Tradition, 1977-1983
}

\author{
Ryan Shaffer
}

\section{Erratum to:}

Chapter 3 in: R. Shaffer, Music, Youth and International Links in PostWar BritishFascism, https://doi.org/10.1007/978-3-319-59668-6_3

The original version of the book was inadvertently published with incorrect placement of footnote reference 145 in Chapter 3, which was corrected. The erratum chapter and the book have been updated with the change. https://doi.org/10.1007/978-3-319-59668-6_3 